\title{
Isu-Isu Permasalahan SDM Pemerintahan
}

\author{
Zulfan Nahruddin ${ }^{1}$ \\ Universitas Muhammadiyah Makassar ${ }^{1}$
}

Manajeman SDM Pemerintahan bertujuan untuk mengoptimalkan kerja-kerja pegawai di sektor publik dari aspek fungsi-fungsi manajemen seperti perencanaan, pelaksanaan, pengoorganisasian, pengendalian atau pengawasan. Hal inilah yang menjadi kesamaan sektor publik dengan sektor privat/swasta terletak pada fungsi-fungsi manajemen yang dikemukakan Gulick \& Urwick (1937), yang lebih dikenal dengan singkatan POSDCORB. meskipun memiliki kesamaan tapi terdapat perbedaan mendasar yaitu karakteristik organisasi dan regulasi atau aturan yangmembatasi pada sektor publik.

Manajemen SDM mempersoalkan hal-hal yang berkaitan dengan SDM yang bekerja pada sektor formal (Zaenuri, 2014). Persoalan ini senantiasa terkait dengan regulasi, aturan, pedoman, dan petunjuk teknis tentang pelaksanaan urusan-urusan tata kelola SDM pemerintahan yaitu rekrutmen pegawai, mutasi pegawai, pelatihan dan pendidikan, pembagian kerja, penilaian dan prestasi kerja, dan pelaksanaan tugas kedinasan.

Berdasarkan data BPS (2017), jumlah Pegawai Negeri Sipil/Aparatur Sipil Negara di Indonesia yang meliputi Jumlah pegawai pusat, provinsi, dan daerah secara keseluruhan berjumlah 4.374.349 pada tahun 2016. Mengalami penurunan dibandingkan tahun 2015 yaitu 4.558.425 jumlah tersebut dipengaruhi oleh banyak Pegawai Negeri Sipil yang pensiun dan dibatasinya penerimaan CPNS. Jumlah pegawai yang ada saat ini mesti memperlihatkan kinerja yang optimal baik yang ada di pusat, provinsi, maupun daerah agar anggaran yang dikelola oleh pemerintah untuk berbagai program kerja dapat dioptimalkan bagi terselenggaranya pelayanan dan kesejahteraan masyarakat

Jumlah pegawai pada tahun 2016 diprediksi dapat menyusut pada tahun berikutnya karena fokus pemerintah saat ini adalah membatasi penerimaan CPNS tenaga teknis administratif diberbagai instansi pemerintahan sehingga dimasa yang akan datang seiring 
Nahruddin, Zulfan. 2018. Isu-Isu Permasalahan SDM Pemerintahan. Open Science Framework.

banyaknya jumlah pegawai administratif yang pensiun maka jumlah pegawai secara keseluruhan juga akan menurun.

Permasalahan SDM pemerintahan tidak hanya persoalan kuantitas jumlah SDM tetapi juga kualitas dan kinerja SDM pemerintahan. Terdapat sejumlah isu permasahan yang dihadapi SDM pemerintahan saat ini. Isu permasalahan SDM pemerintahan adalah segala fenomena yang terkait pelaksanaan fungsi-fungsi manajemen SDM pemerintahan. Terdapat beberapa isu yang disoroti yaitu: (1) rekrutmen, melalui lelang jabatan yang dilakukan baik pusat, provinsi, maupun daerah terkait aturan main dan transparansi dari proses rekrutmen terbuka yang dilakukan; (2) status pegawai honorer meliputi aspek kebijakan yang diberikan oleh pemerintah yang dapat mengakomodir kepentingan pegawai honorer; (3) disiplin kerja SDM pemerintahan terutama perilaku indisipliner ASN serta saksi yang diberikan; (4) produktifitas ASN berupa penggunaan waktu kerja yang efektif dan optimalisasi pencapaian target dari program kerja yang telah dicanangkan.

\section{Daftar Pustaka}

Gulick, L., \& Urwick, L. (1937). POSDCORB. New York: Institute of Professional Administration. Badan Pusat Statistik (2017). Jumlah Pegawai Negeri Sipil Menurut Jenis Kepegawaian dan Jenis Kelamin, Desember 2013 dan Desember 2016. Avaliable at https://www.bps.go.id/statictable/2015/09/08/1798/jumlah-pegawai-negeri-sipilmenurut-jenis-kepegawaian-dan-jenis-kelamin-desember-2013-dan-desember2016.html.

Zaenuri, M. (2015). Manajemen Sumber Daya Manusia di Pemerintahan. Yogyakarta: LP3M UMY. 